\title{
TEKNIK PENINGKATAN PERFORMA ENZIM ASAL MIKROBA LAUT YANG TIDAK DAPAT DIKULTUR
}

\author{
Agustinus Robert Uria, Dewi Seswita Zilda dan Yusro Nuri Fawzya
}

\author{
Balai Besar Riset Pengolahan Produk dan Bioteknoiogi \\ Kelautan dan Perikanan
}

\section{PENDAHULUAN}

Mikroba laut dapat hidup di semua kondisi lingkungan alami. Bahikan penyebarannya menjangkau habitat-habitat ekstrim yang tidak mendukung kehidupan organisme lain pada umumnya. sepert kondisi suhu, pH. tekanan. dan kandungan oksigen yang terlampau rendah atau tinggi. Keanekaragamannya sungguh mencengangkan, yaitu sekitar 10.000 spesies yang berbeda untuk tiap gram tanah atau sedimen (Streit ot al., 2004). Kelimpahannya diperkirakan berada dalam kisaran $10^{4}$ sampai $10^{\top}$ sel per $\mathrm{mL}$ air. Kandungan karbonnya mencapai $50-100 \%$ dari total karbon pada semua tumbuhan darat (Whitman et all. 1998). Adaryya upaya pendatsan komunitas mikroba laut dunia hingga tahun 2020 oleh The International Census of Marine Mi. crobes (ICOMM) tentunya akan menambah catatan panjang tentang keanekaragaman dan kelimpahannya

Tingginya keanekaragaman dan kelimpahan mikroba laut menunjukkan potensinya sebagai sumber paling menjanjikan untuk penemuan produk alami yang bernilai industri. Diantara berbagai bentuk produk alami, enzim termasuk paling diminati dalam dunia industri baik dalam industri kimia, farmasi maupun makanan. Hal ini berkenaan dengan peranannya sebagai katalis yang ramah lingkungan, ekonomis dan bersh (Wahler \& Reymond, 2001).
Ekspiorasi enzim dari mikroba laut biasanya ditempuh dengan cara mengisalasi dan menumbuhkan mikroba dalam bentuk biakan mumi, Kamudian dilakukan seleksi terhadap mikroba penghasil enzim. dilikuti dengan optimasi produksinya di bioreaktor untuk pelipa!gandaan jumlahnya. Namun sayangnya pendekatan yang dikenal dengan sebutan cultivationdependent approach ini dibatasi oleh kenyataan bahwa sebagian besar mikroba (lebih dari $99,8 \%$ dalam hal keanekaragamannya) tidak dan belum dapat dikultur dengan mengunakan teknik-teknik kultivasi kanvensional yang ada (Riesenfeid of at, 2004).

Kemajuan bioteknologi molekuler yang ditandai dengan lahimya metagenomika memungkinkan untuk mengakses enzim dari mikroba laut tanpa perlu mengkulturnya (Arnold, 2001; Handelsman, 2004). Pendekatan motagenomika ini telah diterapkan untuk penemuan sejumlah enzim dari mikroba yang tidak dikuitur seperti lipase, esterase / Henne ef af., 2000), amilase (Rondon et al., 2000), kitinase (Cottrel et al, 1999) dan alkohol dehídrogenase (Knietsch et al, 2003), Pendekatan ini juga sedang diterapkan oleh kelompok peneliti bioteknologi di Balai Besar Riset Pengolahan Produk dan Bioteknologi Kelautan dan Perikanan (BBRP2B) untuk memperoleh enzim protease disamping berbagai enzim lainnya dari mikroba laut yang tidak dikultur yang berasal dari spons.
Walaupun penemuan berbaga: enzim unik dan baru dari mikroba laut sangat terbuka lebar, namun ketika suatu enzim alami direknut untuk aplikasi industri, seringkall performanya tidak memenuhi selera industri, Dengan kata lain. enzim alami seringkail memperlihatkan sifat-sifat yang kurang cocok untuk proses industri, separt labil selama periode waktu yang lama, ticak aktif pada pelanut yang tidak cair, dan tidak dapat menerima substrat spesifik (Van der Cost \& de Graaff, 2002). Untuk itu diperlukan suatu sentuhan molekuler guna membuatnya tampil lebih prima. Sentuhan ini dikenal dengan sebutan mutagenesis.

Dengan mutagenesis, serangkaian sifat fungsional enzim sepert stabilitas panas, aktivitas katalisis dan spesifitas substrat berhasil ditingkatkan (Arnold, 2001). Tulisan ini akan memaparkan bagaimana enzim dari mikroba laut yang tidak dapat dikultur dapat diutak-atik pada tingkat gen untuk membuatnya tampil lebih prima secara fungsional

\section{Dari Metagenomika ke Evolusi Laboratorium}

Metagenomika merupakan cabang genetika yang secara khusus ditujukan untuk mengumpulkan gen-gen langsung dari suatu lingkungan, diikuti dengan menguak informasi genetika yang terkandung di dalamnya (Riesenfeld et al., 2004). Aplikasi pendekatan ini untuk penemuan enzim dari mikroba laut 
(i) Metagenomika

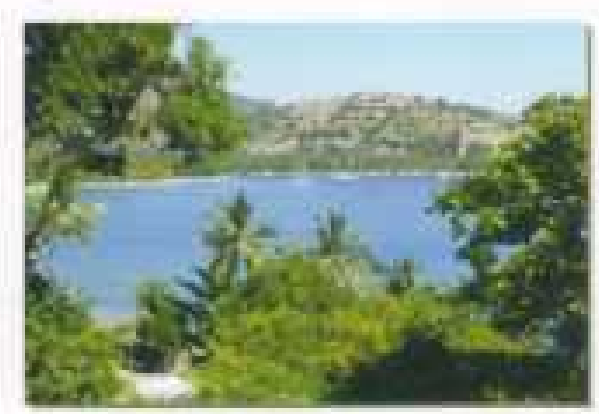

Sumber Mikrobo leut yang. tidak dapat deloiltur
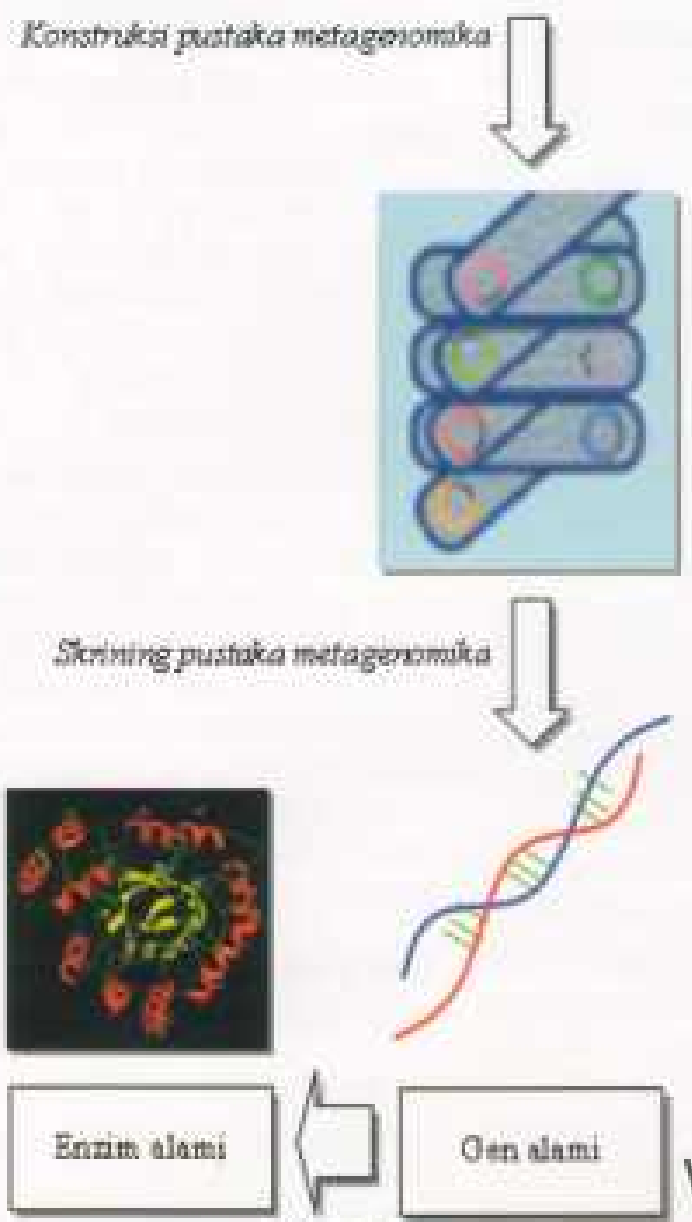

Ekspresi

\section{(ii) Evolusi laboratorium}

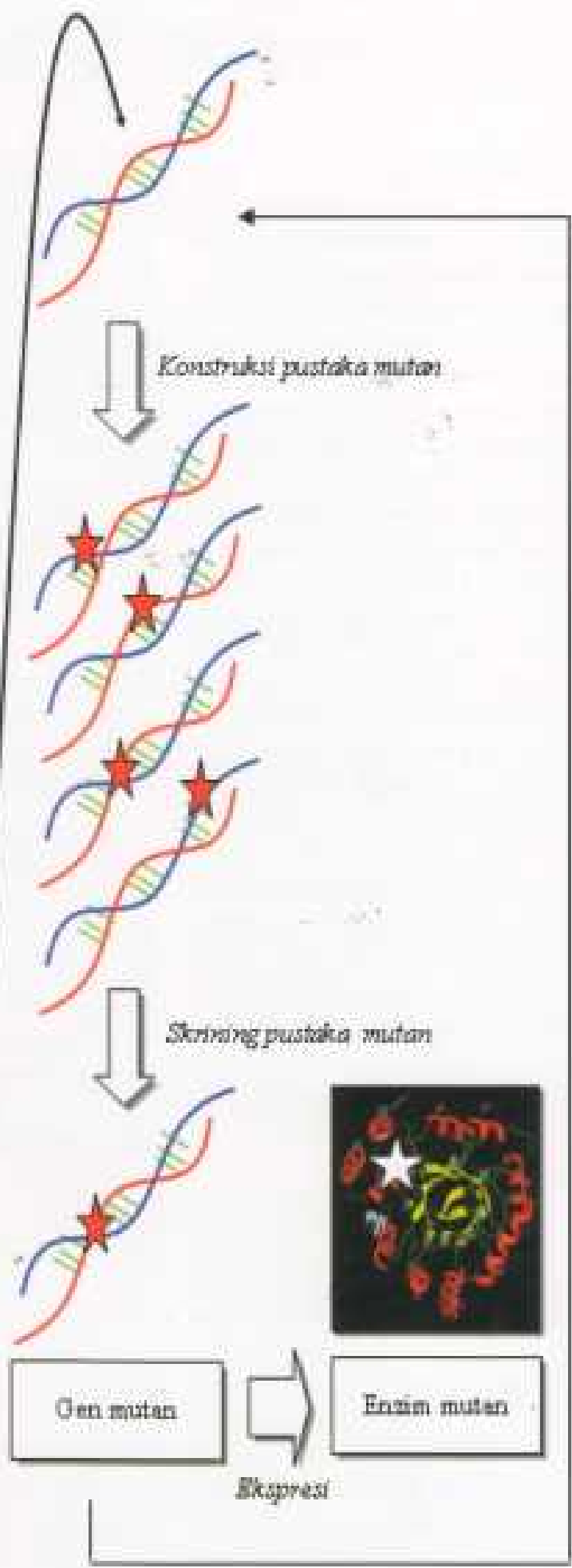

Gambar 1. Perpaduan metagenomika dan evolusi labocatorium untuk maningkatkan penampilan enzim dari mikraba laut yang tidak dapat dikultur. 
yang tidak dapat dikuitur melibatkan (i) konstruksi pustaka metagenomika, (ii) penapisan pustaka metagenomika dan (iii) analisis dăn ekspresi gen (Gambar 1).

Konstruksi pustaka metagenomika dari suatu lingkungan laut dapat didasarkan pada teknologi kloning gen shotgun (Handelsman. 2004). Teknologi ini melibatkan isolasi DNA (deoxymbanucieic aciof) langsung dari sampel lingkungan laut, umumnya dikuti dengan pernotongan DNA tersebut secara parsial. Potongan-potongan DNA. yang relatif besar dikloning ke dalam sel-sel bakteri, biasanya Escherichia colf. Hasil kloning tersebut berupa sekumpulan klon yang disebut pustaka metagenomika.

Pustaka metagenomika kemudian disikrining untuk mendeteks. klon-klon pembawa enzim yang dinginkan (Una ot al., 2006).

Gen yang diperoleh melalul metagenomika dapat diutak-atik melalui mutagenesis untuk menghasilkan gen mutan unggul. Apabila gen mutan tersebut diekspresikan, terbentuklah enzim dengan sifat unggul. Mutagenesis biasanya diawali dengan menelusuri gen yang berperan di balik munculnya satu atau lebih sifat yang tidak dikehendaki. Kemudian informasi genetik yang terkandung dalam gen bersangkutan diungkap dan dianairsis untuk mengetahul faktor penentu sifat: Faktor itu kemudiar dimanipulasi secara spesifik pada urutan basa nukleatidanya guna menghasilkan gen mutan yang dinginkan. Gen mutan ini selanfutnya diekspresikan untuk membentuk enzim mutan dengan sifat-sifat yang diinginkan. Strategi seperti ini secara khusus disebut disain protein rasional atau disain rasional. Strategl ini cukup rumit dan memakan waktu lama karena selain membutuhkan informasi fentang struktur enzimjuga tentang hubungan antara urutan, struktur dan fungsimekanisme kerja enzim (Bornscheuer \& Poht, 2001).

Akhir-akhir ini telah berkembang suatu strategi yang mampu mengubah performa enzim dalam waktu yang relatif singkat. Strategi ini cukup sederhana karena tidak memerlukan dukungan informasi mengenai struktur dan hubungan struktur-fungsi enzim. Prinsip kerjanya adalah menghasilkan berbagai gen mutan dari suatu gen alami dan mengekspresikannya di inang bakteri yang sesuai. Kemudian produk ekspresi, dalam hal ini sekumpulan enzim mutan, diskrining untuk mendapatkan enzim mutan dengan sifat-sifat yang dilnginkan. Karena prinsip kerjanya menyerupai tecri evolusi Darwin dan berlangsung di laboratorium di bawah campurtangan dan kendali manusia, maka strategi ini lebih populer disebut evolusi laboratorium, Sejumiah peneliti menyebutnya dengan istilah evolusil langsung atau evolusi molekuler, Dengan strategi ini. suatu molekul enzim dapat dimanipulasi pada tingkat gen untuk 'melahirkan' turunan unggul. Bahkan dua atau lebih enzim dengan keunggulan yang berbeda dapat 'dikawinsilangkan' untuk melahirkan suatu furunan mutan yang mewarisi semua silat unggul dar induknya. Kelebihan-kalebihan ini telah menerrpatkannya sebogai strategi mutagenesis paling efektit di abad milenium ini.

Evolusi laboratorium mencakup sajumlah tahap (Gambar 1). Pada tahap pertama yang disebut konstruksi pustaka mutan, suatu gen dimanipulasi secara acak untuk menghasilkan berbagai mulannya. Gen-gen mutan ifu kemudian dikfoning dan diekspresikan ke dalam $E$ coll, sehingga menghasilkan kumpulan klon yang disebut pustaka fenotip mutan. Pada tahap kedua yang disebut skrining pustaka mutan, pustaka mutan diskrining untuk menyeleksi klon penghasil enzim mutan dengan fenotip yang diinginkan. Misalnya, untuk memperoleh kion penghasil enzim mutar tahan panas, aktivitas enzim diuji pada suhu yang tinggi. Kemudian gen mutan yang diinginkan dapat disekuens dan. data sekuens dianalisis untuk mengetahul perubahan informasi genetik yang terjadi.

\section{Konstruksi Pustaka Mutan}

Konstruksi pustaka mutan dslam evolusi laboratorium. sebagaimana yang digambarkan di atas, melibatkan produksi berbagai mutan dari suatu gen alami, dilkuti dengan ktoning dan ekspresi gengen mutan ke dalam inang $E$, coil. Hal ini dapat ditakukan melalui mutasi titik (point mutation) dan rekombinasi (recombination). Mutasi Litk dan rekombinasi yang paling populer adalah error prone $P C R$ dan DWA shufling Kedua teknik ini didasarkan pada penerapan PCR (polymerase chain reaction) untuk memodifikasi urutan nukleotida pada gen.

\section{Prinsip Dasar PCR}

Teknik PCR pertama kali diusulkan secara teoritis oleh $\mathrm{H}$. Ghobind Khorana pada tahun 1970. Lims belas tahun kemudian Kary Mullis dan rekan-rakannya di Cetus Corporation mengimplementasikan teori itu melalui eksperimennya tentang penggandaangengen mamalia secara in vitro dengan menggunakan DNA polymerase I dari $E$ coll (Sambrook \& Russel, 2001). Sejak saat itu penggunaan teknik PCR berkembang dengan sangat pesat dan bahkan sekarang telah dapat dilakukan secara otomatis dengan menggunakan mesin thermal cycler atau lebih dikenal dengan sebutan mesin PCR (Sambrook \& Russel, 2001: Karp, 2005), Dengan mesin PCR, daerah target pada DNA dapat diperbanyak sebesar $10^{5} \mathrm{kal}$ 
melalui 25 sikhus dalam waktu paling kurang 57 menit (Prescott, et al, 2002), Salinan DNA yang dihasilkan depat digunakan untuk tujuan kloning, sekuensing dan mutagenesis (Madigan ot al, 2000).

Dalam prakteknya, reaksi PCF dilakukan dengan cara mencampurkan sampel DNA dengan komponen-kornponen berikut: DNA polimerase, keempat deoksiribonukleotida (dNTPs), kofaktor MgCl. dan sepasang oligonuldeotida yang disebut primer. Dalam hal ini, enzim DNA polimerase yang digunakan bersifat tahan panas seperti Taq polymerase dan kedua primer komplemen dengan ujung 3 ' pada daerah DNA yang akan digandakan. Campuran PCR tersebut ditempatkan pada mesin PCR dan kondisi siklus PCR diset untuk sejumlah siklus yang dikehendaki. Setiap siklus mencakup tiga tahap utama. Pada tahap pertama yang disebut denaturasi, campuran PCR diturunkan hingga $60^{\circ} \mathrm{C}$ untuk memungkinkan primer berikatan atau menempel pada setiap untaian tunggal DNA. Pada tahap ketiga yang disebut elongation, suhu dinaikkan hingga sekitar $72^{\circ} \mathrm{C}$ untuk memungkinkan Taq poly. merase menambahkan dNTPs ke ujung $3^{*}$ dari primer hingga membentuk untaian tunggal baru pada untaian tunggal sebelumnya. Siklus seperti ini diulangi berkalikali sehingga hanya dalam beberapa jam, miliaran salinan dari suatu daerah tertentu pada DNA dapat dihasikan (Madigan et al., 2000: Karp, 2005),

Dewasa ini aplikasi PCR telah manyusup ke hampir semua bidang ìmu dasar maupun terapan. Dalam bioteknclogi, teknik PCR digunakan untuk rekayasa protein alau mutagenesis dan analisis keanekaragaman mikrorganisme. Dalam dunia kedokteran, PCR digunakan untuk mendiagnosa berbagai penyakit manusia baik yang digunakan sebagai bagian dari teknologi sidik jari DNA untuk membantu mengungkap kasuskasus kriminal (Prescott et al., 2002). Dalam bidang perikanan dan pertanian, PCR diterapkan untuk mendeteksi parasit pada ikan dan tanaman.

\section{Aplikasi PCR untuk Produksi Gen Mutan}

PCR dapat diterapkan untuk mengubah satu atau lebih basa nukleotida pada salinan dari suatu gen alami. Aplikasi PCR untuk tujuan ini disebut mutasi titik melalui error prone PCR. Hal ini dapat dilakukan melaiui penggantian kation seperti $\mathrm{Mg}^{2 *}$ dengan $\mathrm{Mn}^{2+}$ untuk tujuan mereduksi kondisi optimal dalam reaksi PCR. Cara alternatif adalah menggunakan DNA polymerase yang tidak mempunyai kemampuan proofreading (membaca urutan

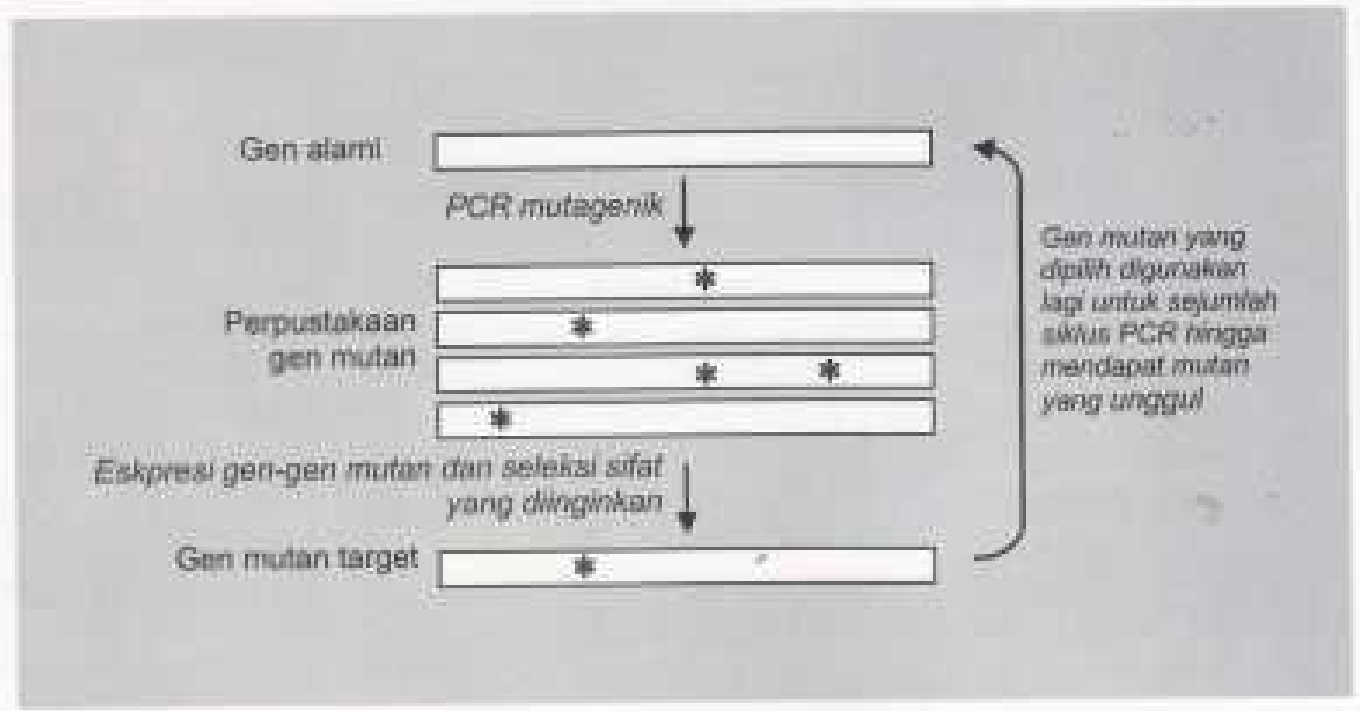

Gambar 2. Error prone PCR yang melibatkan produksi berbagai mutan secara acak dari suatu gen alami (Digambar kembal dari Van der Oost \& de Graff, 2002).

diinkutasi pada $93^{\circ} \mathrm{C}$ untuk memisahkan untaian ganda DNA target menjadi dus untaian tunggal. Pada tahap selanjutnya yang disebut anealing, suhu reaksi disebabkan oleh mikroorganisme patogen, seperti hepatitis. tuberkulosis, AlDs, maupun penyakit genetik (tununan) sepert anernia. Dalam ilmu forensik, PCR nukleotida yang salah dan memperbaikinya). Enzim ini lebih dikenal dengan nama high errorrate polymerase (Amold, 2001; Van der Oost \& de Graff, 2002) 


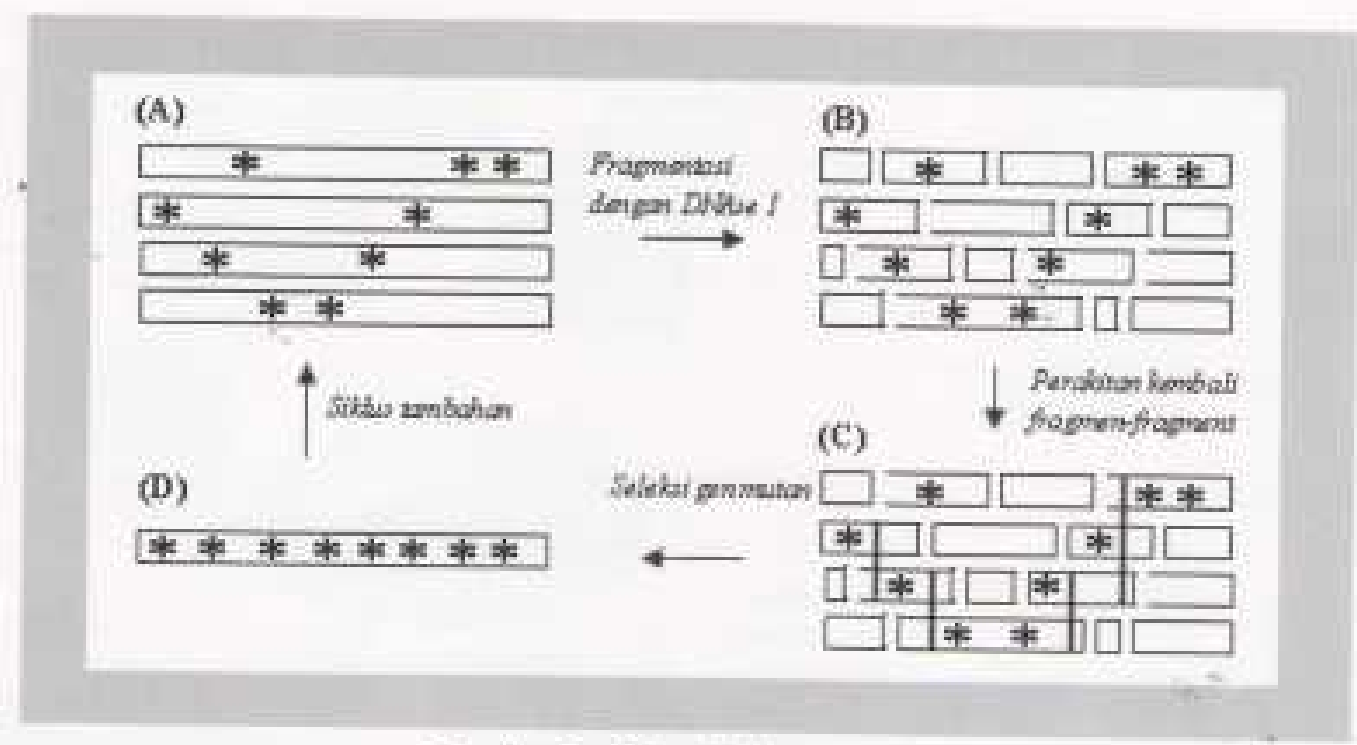

Gambar 3. Siklus DNA shufiling.

Dalam proses error prone PCR sebagaimana yang ditunjukkan pade Gambar 2, suatu gen alami dizunakan sebagai cetakan dalam suatu reaksi PCR untuk menghasilkan sekumpulan gen mutan dengan perubahan pada satu atau beberapa nukleotida. Gen-gen mutan itu kemudian diekspresikan para strain $E$ coli yang sesuai dan diskrining untuk sifat atau fenotip yang dikehendaki. Jike sifat yang diinginkan belum optimal, maka gen mutan target dapat diterapkan lagi dalam sejumlah siklus error prone PCR hingga dijumpai sifat unggul yang diinginkan.

Aplikasi PCR lainnya yang sangat menarik dalam evolusi laboratorium adalah mengawinsilangkan dua atau lebih enzim yang homolog untuk melahirkan suatu tununan mutan yang mewarisi semua sifat unggul dari parentalnya. Aplikasi PCR yang dikenal dengan sobutan DNA shumiling ini mula-mula dimplementasikan oleh Stemmer (1994). Teknik DNA shuffing biasanya melibatkan fragmentasi beberapa gen homolog, dikuti dengan perakitan kembali fragmen-fragmen DNA melalui aplikasi PCR. Dalam prakteknya (Gambar 3), sejumlah gen homolog dengan sifat-sifat yang berbeda dipotong dengan menggunakan enzim DNAse 1. Fragmen-fragmen DNA yang dihasilkan kemudian diterapkan dalam suatu reaksi PCR. Dalam reaksi $P C R$, suatu fragmen dapat berperan sebagai primer yang menempel pada fragmen homolog lainnya, Dengan demikian. rekombinasi terjadi ketika fragmen. fragmen dari suatu gen melakukan polimerisasi terhadap salinan gen lainnya (Stemmer. 1994).

Dengan menggunakan DNA shuffling, gen-gen dari strain mikroba yang berbeda atat bahkan dari spesies yang berbeda dapat dikawinsilangkan satu sama lain untuk menghasilkan gen hibrid baru (Amold, 2001), 'Gen mutan ini dapat mewarisi semua sifat unggul dari gen-gen induknya: Untuk alasan ini, metode ini dipertimbangkan sebagai cara yang sangat ampuh dalam menghasilkan enzim mutan yang tidak ditemukan di alam. Keuntungan metode ini dibanding dengan metode-metode mutagenesis lainnya adalah tingginya jumlah sikłus evolusi molekuler yang dilakukannya (Stemmer, 1994).

\section{Kloning dan Ekspresi Gen Mutan}

Gen-gen mutan yang dihasilkan balk melalui error-prone PCR maupun DNA shuthing periu dikioning dan diekspresikan untuk membentuk perpustakan fenotip mutan. Kloning dan eskpresi gen memerlukan sistem mikrobe yang sesuai. Di antara sistem mikroba yang ada, E coll masih menupakan salah satu inang yang paling diminati dan digunakan secara huas. Ada beberapa alasan utama untuk hal ini, seperti kemampuannya untuk tumbuh dengan cepat pada substrat yang tidak mahal. genetika dan fisiologinya yang telah diketahui dengan baik,ketersediaan sejumlah vektor kloning yang tepat, dan meningkatnya jumlah strain mutannya (Banex, 1999).

Di antara berbagai sistem ekspresi $E$. coll, sistem pET yang dikomersialisasikan oleh Novagen termasuk sistem yang paling baik untuk ekspresi protein rekombinan. Sistem ini menawarkan enam kombinasi inang-vektor dan salah satunya adalah vekter pET24d dan inang $E$, coli BLD21(DE3) (wmwnovagen.com). Kombinasi ini telah sukses digunakan untuk 
ekspresi sejumiah enzim rekombinan, seperti alkohol dehidrogenase sebagaimana yang dilaporkan oleh Machielsen et al. (2006) dan Uria et at, (2006). Kionklon pembawa gen mutan yang aktif secara fungsional dapat diseleksi berdasarkan keberadaan penanda resisten antibiotik dan gen lac I pada vektor (Gambar 4).

\section{Skrining Pustaka Mutan}

Pustaka fenotip mutan selanjutnya perlu diskrining untuk mendapatkan klon-klon penghasil enzim mutan dengan sifat-sifat yang diinginkan. Ini memerlukan metode-metode yang relatif praktis, tidak mahal dan cepat (Wahler \& Reymond, 2001). Metode yang digunakan tergantung pada sifat enzim yang ingin diubah.

Metode-metode skrining yang relate sederhana didasarkan pada seleksi enzim tertuadap parameter lingkungan yang dínginkan sepert tahan panas atau dingin, tahan $\mathrm{pH}$ rondah atau tinggi. Sebagai contoh, protease subtilisin direkayasa melalui evolusi laboratorium dan diskrining untuk sifat tahan atau stabil pada kondisi dingin, sebagaimana yang dilaporkan oleh Taguchi et af., 1998 Dalam hal ini, pustaka mutan dibuat replikanya pada media yang mengandung substrat skim milk dan diinkubasi semalaman pada $37^{\circ} \mathrm{C}$ untuk membentuk klon-klon. Setelah inkubasi tambahan pada $10^{\circ} \mathrm{C}$ selama dua hari, zona bening nampak jalas di sekitar beberapa kion yang menunjukkan bahwa skim milk dihidrolisis pada kondisi dingin,

Pustaka mutan dapat ditujukan untuk menyeleksi enzim mutan dengan enansioselektivitas tertentu. Sebagai contoh, deteksi enzim golongan aldolase terhadap substrat dengan gugus karbonil sebagaimana yang dilaporkan oleh Reymond (2001). Ekspresi enzim

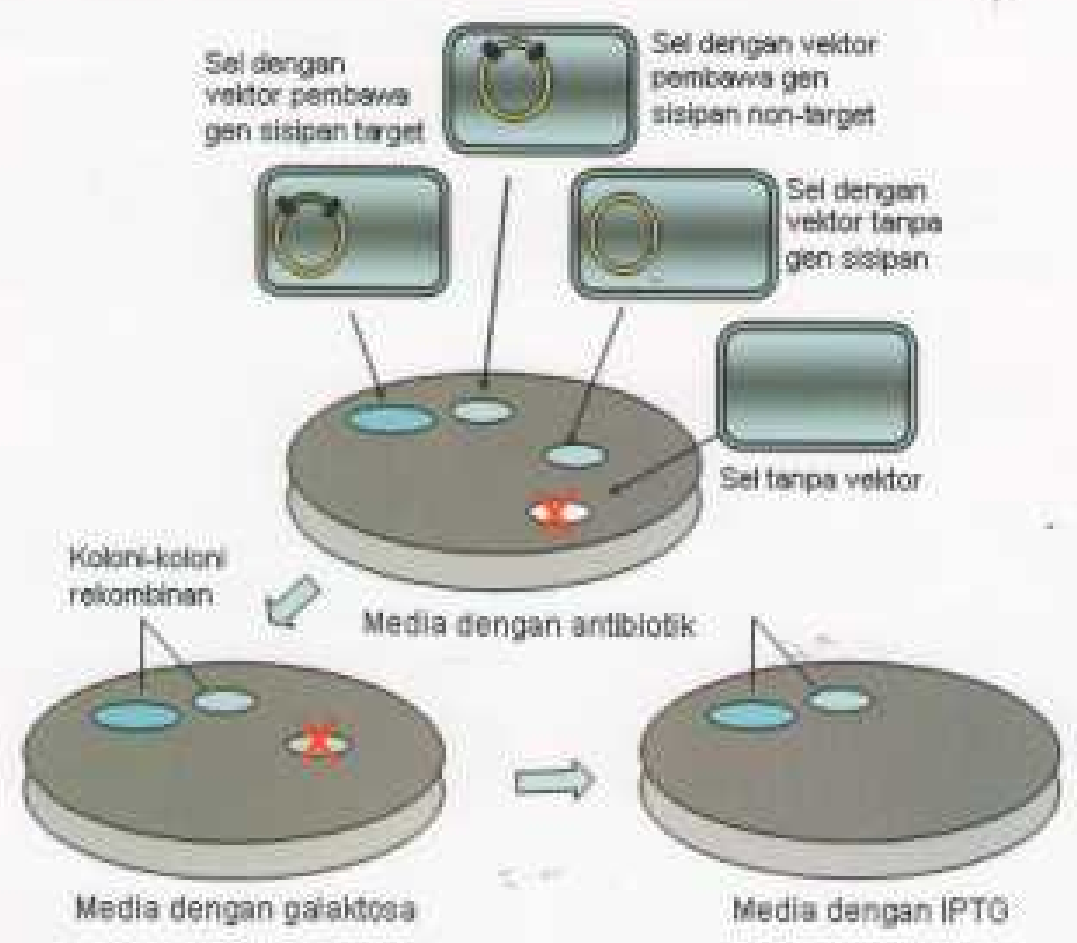

Gambat 4. Seleksi terhadap klon-klon pembawa gen mutan yang aktif secara fungsional. Penambahan antibiotik tertentu ke dalam media pertumbuhan akan memungkinkan hanya klon-kion pembawa vektor tetap hidup. Kemudian adanya $\alpha$-galaktosa dalam media padat memungkinkan pendeteksian klon-klon pembawa gen sisipan. Keberadaan isopropyl-a-D-1thiogalactopyranoside (IPTG) di dalam media menginduksi ekspresi gen-gen mutan. Kumpulan klon-klon pembawa gen mutan yang aktif secara fungsional ini disebut perpustakaan fenotip mutan.

ini oleh klon dapat dideteksi karena kemempuannya mengubah substrat dengan berbagai enansioselektivitas menjadi umbeliferone. Umbeliferone adalah produk fluoresen yang dihasilkan melalui eliminasi senyawa-karbonil. Skrining ini dapat juga diterapkan untuk seleksi alkohol dehidrogenase dengan stereo dan enansio selektivitas tertentu.

Gen mutan target yang diperoleh selanjutnya dapat disekuens (ditentukan urutan nukleotidanya) dan data sekuensnya dianalisis untuk mengetahui secara spesifik penubahan yang terjadi pada urutan asam amino yang disandinya.
Teknik sekuensing yang telah digunakan secara luas adalah pendekatan enzimatis yang dikemukakan oleh Sanger dan Coulson dari MRC-Cambridge, Inggris. Dewasa ini, sekuensing telah dilakukan dengan menggunakan mesin sekuensing (sequencer) yang bekerja otomatis (Karp, 2005). Untuk sekuensing suatu gen, hasilnya dapat diperoleh dalam waktu yang sangat singkat dengan sequencer otomatis.

\section{KESIMPULAN}

Tingginya keanekaragaman dan kelimpahan mikroba laut menunjukkan potensinya sebagal 
sumber paling menjanijikan untuk penemuan produk alami baru yang bernilai industri. Enzim termasuk produk alami yang paling diminatt dalam dunia industri karene reputasinya sebagai katalis yang ramah lingkungan. ekonomis dan bersih. Dengan menggunakan pendekatan metagenomika, berbagai enzim unik dan baru dapat diakses dari mikroba laut yang tidak dapat dikultur.

Walaupun demikian, enzim alami seringkall tidak menunjukkan performa yang sesuei dengan seiera industri, seperti labil selama peniode waktu yang lama, tidak aktif pada pelarut tertentu. dan tidak dapatmenerima substrat spesifik Untuk itu diperiukan suatu sentuhan molekuler yang disebut mutagenesis guns membuatnya tampil lebih prima untuk suatu kondisi reaksi yang dilinginkan.

Evolusi laboratorium dipertimbangkan sebagal strategi mutagenesis paling efaktif di abad milenium ini. Hal ini karena kemampuannya merigubah performa enzim dalam waktu yang relatif singkat tanpa memerlukan dukungan informasi mengenai struktur dan hubungan strukturfungsi enzim. Ada dua metode yang relatif sederhana dalam evolusi laboratorium. yatu errorprone PCR dan DNA shuffling. Dengan menggunakan error-prone $P C R$ khususnya, suatu molekul enzim dapat dimanipulasi pada tingkat gen untuk 'melahirkan' tununan unggul. Dengan DNA shuffing, dua atau lebih anzim homolog dengan keunggulan yang berbeda dapat 'dikawinsilangkar' untuk melahirkan suatu turunan mutan yang mewarisi sumua sifat unggul dari induknya.

\section{UCAPAN TERIMA KASIH}

Kami berterima kasih kepada Ariyant yang telah membaca dan memberi masukan bertiarga terhadap isi manuskrip in.

\section{DAFTAR PUSTAKA}

Amold, F.H. 2001 Combinatorial and computational challenges for biocatalyat design, Nature 409: 253.258

8anex, F, 1999. Recombinant protein expression in Escherichia coli. Cur, Opin Biotectnol. 10:411421.

Bornachoupr, U.T. and Pote, M. 2001. Improved biocatalysts by directed evolution and rafional protein design. Curr. Opirn. Cham Bial 5: $137-143$.

Cottrai, M.T., Moore, J.A, and Kirchman. D. 1999. Chitinases from uncultured marine microorganisms: Appl Environ Microbial 65(6) 2553-2557

Handelsman, I 2004, Motagenomics. Applicution of genomices to uncultured microorganisms. Micrabial. Mol. Biol. Rev, 68/4). $669-685$ :

Herne, A., Schimitz, R.A., Bomeke. M, Gottschalk, G and Daniet, $R$. 2000. Screoning of enviromental DNA libraries for the presence of genes conferring lipolytic activity on Eschenchia coil. Appi Environ. Microbiol 66: 3113 3116.

Karp, G. 2005. Coll and Molecudar Biology: Concepts and Experiments: $4^{\text {th }}$ Edition, John Wiley 8 Sons, Inc. N.J. 780 pp

Knietach, A., Weschkowitz, T. Bowien, $S_{\text {, }}$, Henne, $A$. and Daniel, R. 2003, Construction and screening of metegenomic libraries derivad from ennichment cultures: Generation of a gene bank for genes confferring alcohol oxidoreductase activity on Eschorichis coll. Apol Enviran. Microbiol 69i3) 1408-1416.

Machielsen R. Uria, AR, Kengen, S.W. and van der Oost J. 2006 Hoterologous production and characterization of a thermostable sicohol dehydrogenese that belongs to aldo-keto reductaso superfamily Appl. Envitun. Microbiol 72(1): 233238.

Madigen, M. T., Martinke, J.M. and Parker, d, 2000. Brock Bibiogy of Mircourganisms PranticeHall. Ind. Upper Saddle River.
New darbey, USA. 991 pp. 7

Prescott, L.M, Harley, J.P. and Klein, D.A. 2002. Microbialogy. $5^{\text {t }}$ edition. The McGraw-Hifl Companies, Inc. New York. 1022 pp.

Reymond, d-L 2001. New highthroughput screening 8ssays for biócatalysis. Chimia. 55(12): 1049-1052.

Riesentoid, C.S, Schioss, P.D, and Handelsman, J, 2004. Metagenomics: Genomic analysis of microbial communities. Annu. Rev Gonnt. 38: 525-553.

Rondon, M.R, August P.F., Betterman. A.D., Brady, S.F. Grossman, T.H. Liles, M.R. Lolacono, K. X. Lynoh, B.A. Macrieil, L.A., Miner, C., Tiong. C..., Giman, $M_{11}$ Ostburne. M.S. Clerdy, J., Handeisman, J. and Goodman, R.M. 2000. Cloning the soil metagenome: A stradegy for accessing the genetio and functional diversity of uncultured microorganismsi Appl. Environ. Micrubial, 66(6) 2541-2547.

Sambrook, JE and Russel. D.W. 2001. Molecular Cloning: A laboratory Manual, 2nd ed. Cold Spring Harbor Laboratory Press, Cold Spring Harbor, N.Y.

Stemmer, W.P.C. 19g4. DNA shulling by random fragmentation and reassambly: In vitro recombination for molecuiar evolution. Proc. Netl. Acad. Sol. 91: 10747 . 10751.

Steil. WR, Danicd, R and Jarger, KE. 2004. Prospecting for piocatalysts and driga in the gonomes of non-cultured microorDanisms Cum Opin. Biotecnol. 15. 285-290,

Tagucti, S, Ozaki, A and Momose. H. 1998 . Engineering of a coldadapled protease by sequential random mulagenesis and a screening aystem. Appl. Environ. Microbiol. $84(2)=492-495$.

Unie, A.R., Machislsen, R. Dutilh, B.E.. Hitynen, MAA and Van der Cost. 1. 2006. Alcohol debydrogenases from marine hyperthermo. philic microorganisms and their importance to the pharmaceuticat industry, Intemafional Semvnar and Workshop on Marine Biodiversity \& thew Povential for Devejoping Bio-Pharmaceutical 
industry in indonesia, on the 17. $18^{2}$ of May 2006 at Jakarta.

Van der Cost, J. and de Graati, L 2002. Applied Molecular Geneties. A Teaching Module.
Wageningen University and Research Centre, the Netheriands. Wahler. D. and Reymond,d-L 2001. High-throughput screening for biocatalysts Curc. Opin.
Eiotechnoi, 12.535-544.

Whitman, W.B. Coleman, D.C. and Wiebes, W.J. 1998. Prokaryotes: The unseen majority. Proc. Narl. Acad Sci. USA 95:6578-6583. 